\title{
Decentralization in the Republic of Croatia - A City Budget in the Period from 1996 to 2000
}

Pitarević, Mihaela

Source / Izvornik: Occasional Paper Series, 2003, 7, 1 - 18

Journal article, Published version

Rad u časopisu, Objavljena verzija rada (izdavačev PDF)

https://doi.org/10.3326/ops.16

Permanent link / Trajna poveznica: https://urn.nsk.hr/urn:nbn:hr:242:655879

Rights / Prava: Attribution-NonCommercial-NoDerivatives 4.0 International/ImenovanjeNekomercijalno-Bez prerada 4.0 međunarodna

Download date / Datum preuzimanja: 2023-04-26

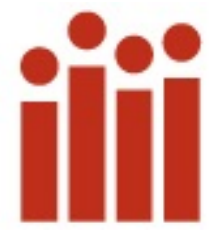

Repository / Repozitorij:

Institute of Public Finance Repository

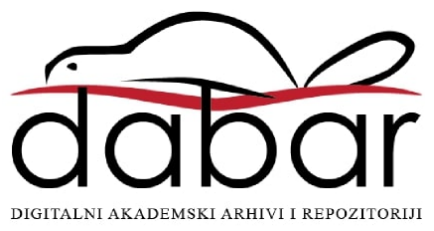




\title{
DECENTRALIZATION IN THE REPUBLIC OF CROATIA \\ - A CITY BUDGET IN THE PERIOD \\ FROM 1996 TO 2000
}

\author{
Mihaela Pitarević
}

Occasional Paper No. 16

March 2003 
DECENTRALIZATION IN THE REPUBLIC OF CROATIA - A CITY BUDGET

IN THE PERIOD FROM 1996 TO 2000

\author{
Mihaela PITAREVIĆ \\ Institute of Public Finance, Zagreb
}

\begin{abstract}
This paper deals with the global decentralization issues, i.e. it explores how, when and why decentralization occurs, the preconditions for a successful decentralization and its advantages. It also examines the situation at the lowest levels of government in Croatia i.e. in a city, with the purpose of presenting the current financial situation and recognizing the key problems connected with decentralization at this level of government. It has been established that Croatia has made a remarkable progress in its decentralization process, although there are still many shortcomings that need to be removed.
\end{abstract}

JEL Classification: H 70, H 61

Key words: decentralization, Croatia, city, budget 


\section{DECENTRALIZATION IN THE REPUBLIC OF CROATIA - A CITY BUDGET IN THE PERIOD FROM 1996 TO 2000*}

\section{Introduction - About Decentralization}

In recent decades the decentralization trend has strengthened all over the world. Decentralization is focused on the devolution of public outlays ${ }^{1}$, revenue and transfers by the central government to lower government levels (Kelly, 2000). It is also focused on effective borrowing, financial management and the administrative structure at the lower levels of government. ${ }^{2}$

When does decentralization occur and why? It has always been known that the market mechanism alone is not sufficient to perform all economic functions (e.g. ensuring legislation, removing of obstacles to competition). Therefore, it is the duty of the public sector policy to direct, correct, and supplement the market activities. Nowadays, public sector is usually very large. Thus in 2000, the share of general government spending in nominal GDP was $44.2 \%$ in EU Member States, and 37.9\% in OECD countries (OECD, 2001). In Croatia, the consolidated general government expenditure was $54.7 \%$ of nominal GDP in 1999 (Ministry of Finance, 2001).

As public sector is usually large, there is hardly a modern or contemporary country that is not divided in local units or that does not know any form of local (self-) government. These results in the necessity to choose between centralization and different levels of decentralization, i.e.:

- deconcentration - redistribution of decision-making within different parts of central government;

- delegation - transfer of responsibility and power from the central government to the partly independent lower levels of government; and

- devolution - transfer of power from the central government to the fully independent lower levels of government (Kelly, 2002).

In reality, there is no optimum choice and the only thing certain is the necessity to regulate the fiscal relations between the central government and lower levels of government in the way, which provides for both financial autonomy and self-government at lower levels of government. However, the fiscal autonomy of the lower levels of government must not jeopardize the fiscal measures on the macro-level, which is normally ensured by the central government.

Theory suggests that the decentralization process should start from distribution of responsibility for outlays, because an estimate of the necessary revenue is only possible if we know functions that the lower levels of government are obliged to perform. In practice this is usually achieved in the way that the lower levels of government preserve the right to decide on functions (outlays), while the responsibility and decisions-making on tax revenue remain within the competence of the central government.

\footnotetext{
* This article is published in Croatian in the journal "Financijska teorija i praksa", 26(4), 2002, pp.793-810, available at: http://www.ijf.hr/financijska_praksa/PDF-2002/4-02/pitarevic.pdf.

As we cannot disclose the source of data we will not name the city.

${ }^{1}$ Budget accounting is usually based on the cash accounting principle, meaning that revenue/receipts and expenditure/outlays and other payments are recognized and recorded in the accounting period when cash is received or disbursed. Consequently, outlays are recognized only when disbursed and are therefore called outlays rather than expenditures. In the Republic of Croatia (RC) there is a tendency towards gradual conversion to accrual accounting principle. This principle is based on the occurrence of a business event, meaning that revenue/receipts and expenditure/outlays are recognized and recorded at the time they occur and not when the payment is actually made or received. Thus, during 2001 and 2002 a new accounting system was introduced, according to which revenue/receipts and expenditure/outlays are recognized on the modified accrual accounting basis, instead of the cash basis accounting. That means that, now in RC, expenditure/outlays are recognized when incurred and revenue/receipts only when they are actually received.

${ }^{2}$ For more information, see Ter-Minassian, 1997.
} 
Local units differ in their economic power or fiscal capacity (i.e. the amount of revenues they can collect). As this is the basis for the financing of public services, they also differ in the capacity to satisfy the needs of the population in their areas. Since the central government tries to provide for a relatively balanced development of all local units (i.e. a similar quantity and quality of provided public goods and services), the inequalities caused by different reasons (social, demographic, political or economic) are reduced by the system of intergovernmental transfers. The system usually includes (1) an optimum revenue sharing between the central government and lower levels of government; and (2) provision of grants to poor units with below-average fiscal capacities.

Evidence proves that the decentralization process is more perceptible in the countries with rapid industrialization and economic development, as well as in countries that have not gone through the war recently. This can be explained by the fact that in these countries it is easier to meet the requirements for a successful decentralization, of which Bahl (2000) mentions the following most important ones:

- easier building of a suitable legal and institutional framework within the state;

- political willingness to carry out decentralization, which results in political devolution, i.e. political decision-making on the fully independent lower levels of government;

- development of facilities for tax collection and provision of public goods and services at lower levels of government simultaneously with the decentralization;

- strong central government capable of monitoring the decentralization process (primarily in terms of subsequent control, technical assistance and management at lower levels of government), and developing the appropriate indicators to show whether the decentralization goals have really been achieved. Concerning the goals, it is important to focus on the output rather than input, which means that the responsibility for spending should be replaced by the responsibility for the achieved results;

- the lower level legislative and executive authorities have been elected at these levels, and since the budget of lower levels of government is approved on these levels the authorities can exercise control over some sources of revenue and have certain rights to borrow money;

- transparent and clear system of grants;

- well-defined distribution of functions (outlays) among various levels of government;

- up-to-date, transparent and accurate accounting at lower levels of government;

- active role of society, non-government organizations and private sector;

- lower levels of government learn from one another.

However, it is worth noting that the decentralization is not a universal remedy, and the role of numerous other factors like the economy of scope, externalities, etc., is also very important. Decentralization is not an end but a means to obtain some benefits that it can produce, which are as follows:

1. It provides more efficiency and effectiveness in satisfying the local population's needs in terms of quantity, quality and price of public goods and services. In various local government units the population has different preferences concerning the quality, quantity and price of public goods and services, and the costs of providing these goods and services are also different in each local unit. Therefore, according to the correspondence principle, public goods and services should be provided by the local unit that has control over the minimum territory in which the benefits of these goods and services can be used and the costs covered.

2. Growing responsibility of lower government units to their population (those who elected the government), because the revenue collected at a certain level of government is linked with its outlays. This can facilitate the mobilization of revenues.

3. Reducing the coordination overlap at different levels of the state government.

4. Encouraging competition between various local levels of government and innovations in the provision of public gods and services. 


\section{The Results of Decentralization in Croatia}

Croatia has already made significant progress in the decentralization process, but the current system obviously has numerous weaknesses ${ }^{3}$ and should therefore be modified. The purpose of this paper is to analyze the budget of a city in the period from 1996 to 1999 or $2000^{4}$. It is aimed at presenting the results of decentralization in Croatia giving the example of the financial situation of a local government and self-government unit, presenting the problems with which it is confronted and proposing solutions for the improvement of the city's current condition. This city was analyzed because only its data were available.

The used data originate from the annual account of the city budget and the relevant documentation for 1996, 1997, 1998 and 1999, as well as the reports on the overall city revenue and expenditure outturns (for 1996, 1997 and 1998) issued by the Ministry of Finance of the Republic of Croatia, Budget Preparation and Consolidation Department. The budget for 2000 was taken from the City Bulletin No. 7/1999. We emphasize that, although the paper is based on the status and data until 1999/2000 it would be interesting to update these figures (if more recent data will be available) to assess the impact of the changes that occurred in the meantime on the described problems, i.e. the state of the budget, its transparency and reliability.

At the very beginning, it should be noted that many problems arose during the analysis. The most serious among them are the following:

- It is assumed that the accounting records at the city level have been kept in an orderly, accurate and up-to-date manner.

- During the analyzed period, the charts of accounts of budgetary beneficiaries underwent many changes (in classification), which resulted in non-comparability of certain items and/or in different figures on the same items in different documents.

- A major problem has also been the application of the cash basis accounting, which, in the circumstances of illiquidity, arrears, uncollected receivables and budget debt, contribute to the non-transparency of the situation.

- Numerous documents and data are not available, e.g. the list of all guarantees issued, or the list of uncollected receivables and arrears.

Given the numerous problems, although the data have been analyzed in good faith, it is likely that they are not quite accurate and should therefore be regarded with precaution.

\section{The Example of the Financial Situation of a Local Unit}

The city is one of 568 local units in the Republic of Croatia. Over the last decade, the overall economic situation in the city has not been very stable. In the period from 1991 to 1995 the city and its surroundings were devastated by war. After the war, the economic situation in the area has gradually improved. Nevertheless, most of the economic potential of the area from the pre-war period was destroyed (hotels and factories were devastated and many households were burned down or occupied). An additional obstacle to rapid recovery and reconstruction has always been the neighboring Yugoslavia and its local developments. The greater city area was hit by several earthquakes (in 1995, 1996 and 1997) suffering severe material damage. This has deprived the city of using its tourist and/or economic potentials for many years. All this has been happening in the circumstances of widespread illiquidity, high unemployment, low economic growth and numerous other problems connected with the Croatian economy and financial system.

The city budget (hereinafter: budget) involves all the above mentioned problems.

\footnotetext{
${ }^{3}$ For weaknesses in the system of financing the units of local government and self-government in the Republic of Croatia, see Bajo, 1999.

${ }^{4}$ I would like to express my special gratitude to the staff members of the city's Tax Administration and the Ministry of Finance of the Republic of Croatia for the provided data and assistance. The expressed views represent the author's attitude and not necessarily the views of the above mentioned institutions.
} 
1. On the revenue side there is a shortfall in realized budget revenues (large amount of uncollected receivables) and low state grants to the city.

2. On the expenditure side there are huge current outlays (particularly transfers for culture and public utilities).

3. The financing account reveals increasing liabilities that arise from borrowing, co-debtor arrangements and issued guarantees.

4. Another major problem is the lack of capital assets register and unregulated propertyrights relations with other municipalities.

\subsection{General Budget Items}

Table 1. City Budget (in million kuna), cash basis

\begin{tabular}{lrrrrr} 
& \multicolumn{5}{c}{ Year } \\
\hline Tax revenues and contributions - tax & 1996 & 1997 & 1998 & 1999 & Plan 2000 \\
Capital revenues & 33.7 & 35.4 & 37.4 & 33.0 & 33.3 \\
Supports, subsidies and grants & 0.1 & 0.1 & 1.1 & 2.6 & 5.1 \\
Other revenue and receipts - non-tax & 6.3 & 4.2 & 1.8 & 1.8 & 9.1 \\
\hline Total revenue and receipts & 17.6 & 20.2 & 29.1 & 43.4 & 45.5 \\
\hline Current outlays & 57.7 & 59.9 & 69.4 & 80.7 & 93.5 \\
Capital outlays & 49.2 & 67.2 & 64.4 & 54.7 & 66.0 \\
Given loans and share in capital & 0.7 & 0.5 & 3.3 & 22.8 & 14.9 \\
Repayment of the principal & 0.0 & 0.0 & 0.9 & 3.9 & 12.2 \\
Reserve & 0.0 & 0.0 & 1.5 & 0.2 & 0.3 \\
\hline Total outlays and other payments & 0.1 & 0.2 & 0.2 & 0.1 & 0.1 \\
\hline Surplus & 50.0 & 67.9 & 70.4 & 81.7 & 93.5 \\
Cover of deficit by surplus from prev. years & 7.7 & 0.0 & 0.0 & 0.0 & 0.0 \\
\hline
\end{tabular}

Source: The City Income and Expenditure Accounts for the Period 1996 through 2000, from the City Annual Budget Proposals.

Chart 1. City Budget, Cash Basis (in million kuna)

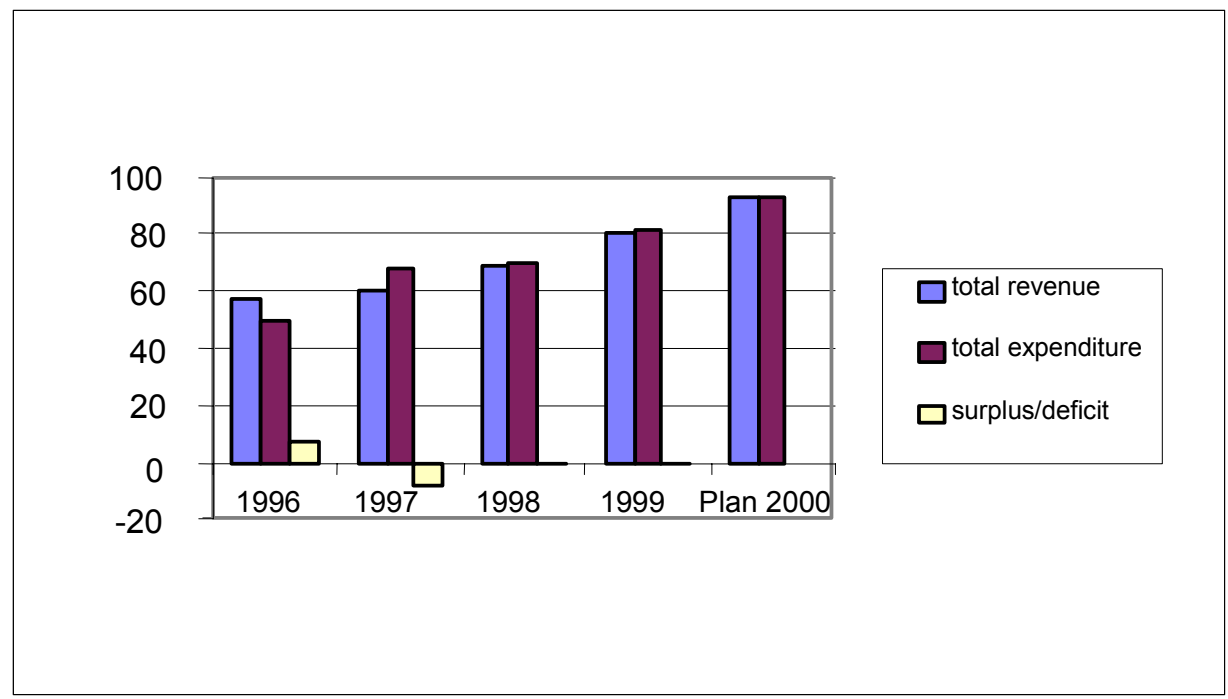

Source: Table $1^{5}$.

\footnotetext{
${ }^{5}$ Although the table and the chart include the data from the plan for 2000, they are not used in the analysis because they do not represent the outturns. Therefore, they are only used for reference.
} 
Table 1 and Chart 1 show that in the period from 1996 to 1999, budget expenditure were growing parallel with budget revenues. Due to a sustained growth in budget revenue and expenditure, the budget reached 81 million kuna in 1999. A surplus (7.6 million kuna) was only recorded in 1996, and, according to the notes from financial reports, that was the consequence of an increase in realized tax revenue and unplanned grants ${ }^{6}$ from the government budget in late 1996. Since 1997, there has been a deficit in the budget covered by the surplus accumulated in the previous years. However, it should be mentioned that, due to the cash basis accounting, the presented budget does not reflect the total balance, because there are no data on uncollected receivables or arrears of the city and obligations arising from borrowing, co-debtor arrangements and issued guarantees (city debt) ${ }^{7}$.

Therefore, Table 2 presents the city budget by applying the accruals basis accounting (i.e. by including uncollected receivables, unsettled budget liabilities and city debt). This results in a more realistic picture of the budget finances with much larger total budget revenue and expenditure and a larger surplus in 1996 and 1997, but an increased deficit in 1998 and 1999.

Table 2. City budget, (in million kuna), accruals basis

\begin{tabular}{lrrrr} 
& 1996 & 1997 & 1998 & 1999 \\
\hline Uncollected receivables & 23.7 & 29.6 & 32.5 & 31.3 \\
Collected revenue & 57.7 & 59.9 & 69.4 & 80.7 \\
\hline Total revenue & 81.3 & 89.6 & 101.9 & 111.9 \\
\hline Total outlays & 50.0 & 67.9 & 70.4 & 81.7 \\
Other liabilities & 0.1 & 4.2 & 11.4 & 21.9 \\
City debt & 0.0 & 0.0 & 25.0 & 31.4 \\
\hline Total expenditure & 50.1 & 72.1 & 106.8 & 135.0 \\
\hline Surplus/deficit & 31.2 & 17.4 & -4.9 & -23.1 \\
\hline
\end{tabular}

Source: The City Income and Expenditure Accounts for the Period 1996 through 2000, from the City Annual Budget Proposals.

Table 3 and Chart 3 provide a comparison between the basic items of the budget drawn up by applying cash basis accounting and the accruals basis accounting.

Table 3. Comparison between the basic items of the budget drawn up by applying cash basis accounting and the accrual basis accounting (in million kuna)

\begin{tabular}{lrrrrrrrr} 
& 1996 & $1996^{*}$ & 1997 & $1997^{*}$ & 1998 & $1998^{*}$ & 1999 & $1999^{*}$ \\
\hline Revenue and receipts & 57.7 & 81.3 & 59.9 & 89.6 & 69.4 & 101.9 & 80.7 & 111.9 \\
Outlays and other payments & 50.0 & 50.1 & 67.9 & 72.1 & 70.4 & 106.8 & 81.7 & 135.0 \\
Surplus/deficit & 7.7 & 31.2 & -8.0 & 17.4 & -0.9 & -4.9 & -1.0 & -23.1 \\
\hline
\end{tabular}

Source: The City Income and Expenditure Accounts for the Period 1996 through 2000, from the City Annual Budget Proposals. The budget was drawn up by applying accruals basis accounting.

* Basic items of the budget drawn up by applying accruals basis accounting.

\footnotetext{
${ }^{6}$ Supports have mainly been paid in for a partly alleviation of the consequences of the earthquakes in the county area, and as special-purpose payments on behalf of the administrative departments for reconstruction and communal services.

${ }^{7}$ These data would be included in the budget if the accruals basis accounting were implemented.
} 
Chart 3. Comparison between basic items of the budget drawn up by applying cash basis accounting and accruals basis accounting (in million kuna)

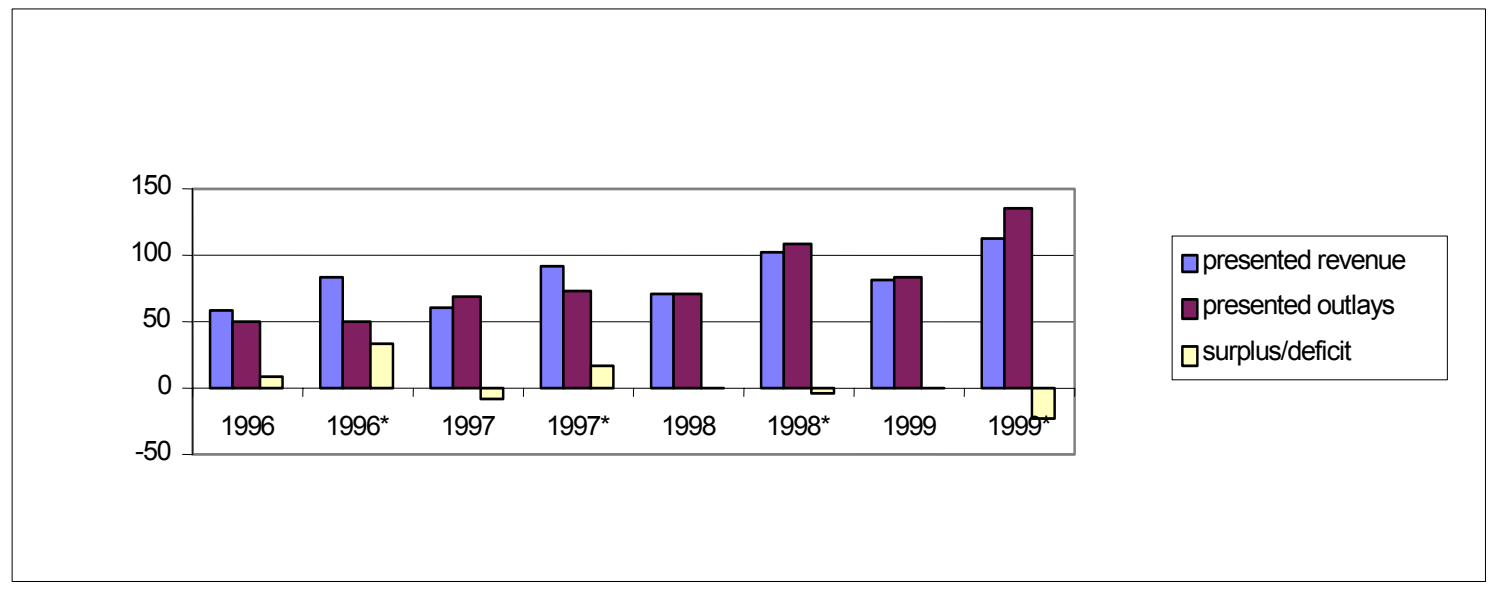

Source: Table 3.

* Basic items of the budget drawn up by applying accruals basis accounting.

The application of cash basis accounting in the circumstances of serious illiquidity problems in the Republic of Croatia results in not presenting the actual and complete financial situation of budgetary beneficiaries (depending on the amount of uncollected receivables, arrears and the size of debt). Table 3 and Chart 3 suggest that in 1999 the budget ended up with a surplus of 7.7 million kuna (cash basis accounting), but the surplus would have been four times larger (around 31.2 million kuna) had the accruals basis accounting been applied. Moreover, according to cash basis accounting the budget had a deficit of 7.9 million kuna in 1997, while the accruals basis accounting (recording of uncollected receivables) would have resulted in a surplus of around 17.4 million kuna in that year.

If cash basis accounting is applied, the deficit recorded in the 1999 budget is significantly smaller than if the accruals basis accounting is applied. More specifically, the accruals basis accounting and recording of arrears and city debt in 1998 and 1999 (amounting to 36 million kuna and 53 million kuna, respectively), along with uncollected receivables, would result in 1998 in a five times larger budget deficit than that based on the cash basis accounting. In 1999, the deficit would be as much as 23 times larger than that reported in the budget. Consequently, though it may be better if uncollected receivables are not recorded as revenues, it is bad if arrears are not recorded in the budget, and thus the actual expenditure side of the budget is not presented.

\subsection{The Revenue Side of the Budget}

The central government of the Republic of Croatia sets the maximum tax rates for local taxes, defines revenue sharing between the central government and lower levels of government, and controls the system of transfers for the purpose of fiscal equalization (Šimović, 2000:127). The system includes optimum revenue sharing and giving grants to lower income units, which have below-average fiscal capacities for revenue collection and financing of public services in their respective territories.

According to Kelly (2000), there are four models of distribution of revenue sharing between the central government and lower levels of government ${ }^{8}$. By following the German example, Croatia implements tax sharing and surtax.

According to Table 4, the richest sources of revenues for the city budget are tax revenues (income tax and surtax) and non-tax revenues (utility fees and revenue from rentals).

\footnotetext{
${ }^{8}$ This includes: taxes of lower levels of government, surtax, tax sharing and sharing of collected revenues.
} 
Table 4. Size and Structure of Total Budget Revenue

\begin{tabular}{lrrrrrrrr} 
& \multicolumn{2}{c}{1996} & \multicolumn{2}{c}{1997} & \multicolumn{2}{c}{1998} & \multicolumn{1}{c}{1999} \\
\hline & $\begin{array}{r}\text { million } \\
\text { kuna }\end{array}$ & $\%$ & $\begin{array}{r}\text { million } \\
\text { kuna }\end{array}$ & $\%$ & $\begin{array}{r}\text { million } \\
\text { kuna }\end{array}$ & $\%$ & $\begin{array}{r}\text { million } \\
\text { kuna }\end{array}$ & $\%$ \\
\cline { 2 - 9 } Tax revenue & 33.7 & 58.4 & 35.4 & 59.0 & 37.4 & 53.9 & 33.0 & 40.8 \\
Capital revenue & 0.1 & 0.2 & 0.1 & 0.2 & 1.1 & 1.6 & 2.6 & 3.2 \\
Supports, subsidies & 6.3 & 10.8 & 4.2 & 7.0 & 1.8 & 2.6 & 1.8 & 2.2 \\
Non-tax revenues & 17.6 & 30.6 & 20.2 & 33.8 & 29.1 & 41.9 & 43.4 & 53.7 \\
Total revenue & 57.7 & 100.0 & 59.9 & 100.0 & 69.4 & 100.0 & 80.7 & 100.0 \\
\hline Source: The City Income and Expenditure Accounts for the Period 1996 through 2000, from the City Annual Budget \\
$\quad$ Proposals.
\end{tabular}

The share of tax revenue in the total budget revenue fell from about $59 \%$ in 1996 to some $40 \%$ in 1999 , and this shortfall in tax revenue of the budget is largely made up for by non-tax revenue. They account for 30\% of total revenue in 1996 and as much as 54\% of total budget revenue in 1999. Capital revenue is negligible (although its share grows), while the share of supports, subsidies and grants (hereinafter: grants) trended downwards and fell from about 11\% in 1996 to approximately $2 \%$ in 1999 . Further analysis of budget revenue demonstrates two major problems.

\section{Problem 1: Large Amount of Uncollected Receivables}

The above mentioned overall illiquidity problem in the Republic of Croatia resulted in accumulation of uncollected budget receivables. Table 5 provides the data on the amount of uncollected receivables and collected budget revenue from 1996 to 1999.

Table 5. Amount of uncollected receivables and collected budget revenues, 1996-1999

\begin{tabular}{lcccccccc} 
& \multicolumn{2}{c}{1996} & \multicolumn{2}{c}{1997} & \multicolumn{2}{c}{1998} & \multicolumn{2}{c}{1999} \\
\hline & $\begin{array}{c}\text { million } \\
\text { kuna }\end{array}$ & $\%$ & $\begin{array}{r}\text { million } \\
\text { kuna }\end{array}$ & $\%$ & $\begin{array}{r}\text { million } \\
\text { kuna }\end{array}$ & $\%$ & $\begin{array}{r}\text { million } \\
\text { kuna }\end{array}$ & $\%$ \\
\cline { 2 - 9 } $\begin{array}{l}\text { Uncollected } \\
\text { receivables (1) }\end{array}$ & 23.7 & 29.1 & 29.6 & 33.1 & 32.5 & 31.9 & 31.3 & 27.9 \\
$\begin{array}{l}\text { Collected } \\
\text { revenue (2) }\end{array}$ & 57.7 & 70.9 & 59.9 & 66.9 & 69.4 & 68.1 & 80.7 & 72.1 \\
$\begin{array}{l}\text { Total revenue } \\
(1)+(2)\end{array}$ & 81.3 & 100.0 & 89.6 & 100.0 & 101.9 & 100.0 & 111.9 & 100.0 \\
\hline
\end{tabular}

Source: Income and Expenditure Accounts for the period 1996 through 2000, City Annual Budget Proposals.

The data suggest that the average of $30 \%$ of revenue per annum, or 29 million kuna, remained uncollected. The table also shows that the absolute amount of receivables has mainly grown over time. With widespread illiquidity, the growth of uncollected receivables was also influenced by a difficult economic situation in the greater county area, and, according to the State Audit findings, the largest debtors to the city were legal persons in hotel business, trade, catering and industry. As shown in Table 6, in 1998 they mainly owed utility fees ${ }^{9}$ (approximately 16.7 million kuna or $51 \%$ of total receivables), rental fees for immovable and movable property owned by the city (around 9 million kuna or $27 \%$ of total receivables of the city).

\footnotetext{
${ }^{9}$ The revenue from utility rates is regulated by the Law on Public Utility Services. Utility rates are part of the budget revenue of the units of local self-government and are paid by owners or users of housing facilities, business premises, garages, building land used for performing business activities and building land not built upon. The revenues from utility rates are spent for drainage of atmospheric waters, public area sanitation, public area maintenance, maintenance of unclassified roads and public lighting.
} 
Table 6. Summary of uncollected receivables as at 13 December 1998 (in million kuna and in \%)

\begin{tabular}{lrr} 
Receivables & $\begin{array}{r}\text { million } \\
\text { kuna }\end{array}$ & $\%$ \\
\hline 1. Utility rates & 16.7 & 51 \\
2. Rentals & 8.8 & 27 \\
3. Trading name tax & 2.5 & 8 \\
4. Loans to public enterprises & 2.2 & 7 \\
5. Secondary residence tax & 0.7 & 2 \\
6. Advertisement tax & 0.5 & 2 \\
7. Use of public area charge & 0.4 & 1 \\
8. Payments of security and advance payments & 0.3 & 1 \\
9. Other receivables & 0.6 & 2 \\
\hline Total receivables & 32.8 & 100 \\
\hline Source: Summary of the City Budget Receivables and Liabilities as at 31 December & $1998 ;$ \\
\multicolumn{1}{c}{ notes from the financial reports for 1998, the city, 26 February 1999.} &
\end{tabular}

As shown in Table 6, a part of the receivables relates to loans granted to public enterprises $(7 \%$ of total receivables as at 31 December 1998). It is worth mentioning, and this is also indicated by the financial reports and the notes, that the city regularly extends new loans after the previously granted ("old") loans have fallen due, and thus mainly extends the time of repayment of the majority of these old loans. To put it simply, the loans are not repaid, but the time of their repayment is extended.

\section{Problem 2: Insufficient Grants}

Fiscal policy uses the system of intergovernmental transfers to bridge the gap between revenue and expenditure, to increase the effectiveness of the central government expenditure or to react publicly to external effects ${ }^{10}$, or it uses transfers for political purposes. To improve the efficiency of the system, it is necessary to use various types of grants for resolving various problems (Weist, 2000). These are:

1. Revenue sharing and general-purpose grants (block grants) for bridging the fiscal gap;

2. Special-purpose grants with a participation of lower levels of government to rectify the problems caused by external effects;

3. General-purpose grants defined by a formula ${ }^{11}$, for the equalization of fiscal capacity of the local government units.

It is necessary to determine precisely how, to whom and when the grants will be given and to establish a reliable system of financial reporting, control and assessment.

In most Central European countries grants have become an increasingly important source of local units' revenue. They accounted for about $26 \%$ and $28 \%$ of the total local budgets' revenues in 1997 and 1998 respectively.

\footnotetext{
${ }^{10}$ For more details, see Rosen, 1999.

${ }^{11}$ When using the formula as a method of funds allocation, the formula has to be transparent and simple. Normally, some changes are expected over time, so that the formula will have to be revised and its deficiencies rectified after a certain number of years.
} 
Table 7. Local Government Revenues in Central European Countries in Total Revenues (in \%)

\begin{tabular}{lcccc} 
Country & \multicolumn{2}{c}{$\begin{array}{c}\text { Own revenue and revenue shared with } \\
\text { the central government }\end{array}$} & \multicolumn{2}{c}{ State grants } \\
\hline & 1997 & 1998 & 1997 & 1998 \\
\cline { 2 - 5 } Estonia & 60.7 & 54.2 & 24.5 & 22.5 \\
Latvia & 54.4 & 54.1 & 32.4 & 32.7 \\
Lithuania & 66.5 & 73.6 & 16.3 & ----- \\
Poland & 59.5 & 58.2 & 38.3 & 39.7 \\
Czech Rep. ${ }^{a}$ & 52.0 & 51.5 & $22.6^{b}$ & $22.1^{b}$ \\
Slovak Rep. & 36.7 & 39.5 & ---- & ----- \\
Hungary & 35.5 & 37.2 & 29.2 & 31.7 \\
Slovenia & 42.6 & 41.2 & 21.7 & 21.5 \\
\hline
\end{tabular}

Source: Horváth, 1999.

${ }^{a}$ Exclusive of transfers

${ }^{b}$ Inclusive of grants to district offices

The most disputable is the system of grants, which proved to have the largest number of deficiencies, in RC (Šimović, 1999). The amount of grants given to lower levels of government in $\mathrm{RC}$ is small compared with other transition countries. This is primarily caused by the fact that intergovernmental transfers are exclusively provided as a support to financially weaker lower levels of government, and not as an instrument for financing a certain level of public expenditure at all lower levels of government.

The data in Table 8 show a decrease of grants as a share of the city budget ${ }^{12}$.

Table 8. Grants- to-Total City Budget Revenue Ratio

\begin{tabular}{lrrrrrrrr} 
& \multicolumn{2}{c}{1996} & \multicolumn{2}{c}{1997} & \multicolumn{2}{c}{1998} & \multicolumn{2}{c}{1999} \\
\hline & $\begin{array}{r}\text { million } \\
\text { kuna }\end{array}$ & $\%$ & $\begin{array}{r}\text { million } \\
\text { kuna }\end{array}$ & $\%$ & $\begin{array}{r}\text { million } \\
\text { kuna }\end{array}$ & $\%$ & $\begin{array}{r}\text { million } \\
\text { kuna }\end{array}$ & $\%$ \\
\cline { 2 - 9 } Grants & 6.3 & 10.8 & 4.2 & 7.0 & 1.8 & 2.6 & 2.0 & 2.2 \\
Total budget revenues & 57.7 & 100.0 & 59.9 & 100.0 & 69.4 & 100.0 & 81.0 & 100 \\
\hline
\end{tabular}

Source: The City Income and Expenditure Accounts for the Period 1996 through 2000, from the Annual Budget Proposals.

Despite the relatively difficult economic situation of the city, the support of higher levels of government in the form of grants has fallen from about $11 \%$ of total budget revenue in 1996 to $2 \%$ in 1999 . The city has offset the lower budget revenues from grants mainly by higher realization of own non-tax revenue.

\footnotetext{
${ }^{12}$ The method of allocation of grants is regulated by Articles 48 and 49 of the Local Self-Government and Administration Financing Law. According to the Law, a county in the area of which the revenue of the county, the municipalities and cities, assuming the average tax burden, is below the national level (with the exception of the City of Zagreb) is given a grant from the state budget to the amount of the difference between its realized per capita revenue and $75 \%$ of the national per capita average. A grant is not provided to a county in the area of which the surtax on income tax is below 1.0 and the rates of taxes, as well as their amounts are lower than the minimum rates prescribed by law. The same criterion applies to the fiscal equalization at the county level, with the county average income per capita used as the base for fiscal equalization.
} 


\subsection{Budget Expenditure}

We have already mentioned that fiscal decentralization should start by the devolution of responsibilities for expenditure to lower levels of government. However, a problem arises when the decision is made which public goods and services should be provided at each particular level of government. Municipalities and cities in the Republic of Croatia have a better-defined scope of public self-government tasks and the responsibilities for their fulfillment than counties, which still have no clearly defined self-government and administrative authority. Given the differences between local units, the situation could be improved by clearly defining which basic public functions shall be performed by local units, taking care that the functions do not overlap, and then some additional public functions should be assigned to the more developed ${ }^{13}$ local units.

The data in Table 9 point to the current outlays as the largest in the observed period.

Table 9. Composition of the city budget expenditure (in \%)

\begin{tabular}{lrrrr} 
Expenditure & 1996 & 1997 & 1998 & 1999 \\
\hline $\begin{array}{l}\text { 1. Current outlays } \\
\text { 1.1. Employment outlays, expendable supplies and regular } \\
\quad \text { maintenance }\end{array}$ & 98.5 & 99.0 & 91.6 & 67.0 \\
$\begin{array}{l}\text { 1.2. Current outlays for materials and services } \\
\text { 1.3. Current transfers to citizens, households and non- }\end{array}$ & 6.5 & 14.7 & 16.4 & 17.7 \\
$\quad$ financial organizations (culture) & 48.5 & 44.7 & 44.6 & 27.0 \\
$\begin{array}{l}\text { 1.4. Other current transfers and grants (utilities) } \\
\text { 2. Capital outlays }\end{array}$ & 27.0 & 34.8 & 25.5 & 12.7 \\
3. Granted loans and the share in capital & 1.3 & 0.8 & 4.7 & 27.9 \\
4. Repayment of principal & 0.0 & 0.0 & 1.3 & 4.7 \\
5. Reserve & 0.0 & 0.0 & 2.2 & 0.3 \\
\hline Total & 0.2 & 0.3 & 0.3 & 0.1 \\
\hline Source: The City Income and Expenditure Accounts for the Period 1996 through 2000, from the City Annual Budget \\
$\quad$ Proposals.
\end{tabular}

In 1996, current outlays accounted for $98 \%$ and in 1999 for $67 \%$ of total budget expenditure. Over the years, their amount has gradually decreased, while capital outlays have increased. Thus, in 1998 capital outlays participated with about 5\% in the total budget expenditure, and in 1999 they reached the maximum of around $28 \%$ of the total budget expenditure. This resulted from compensation of a major receivable (charges for utility services and rentals) for office buildings in the amount of about 18 million kuna. This compensation was reported as capital outlay ${ }^{14}$ for office buildings (although no cash was actually paid out).

This "fictitious capital outlay" contributed to the change in actual composition of expenditure in 1999. Table 10 provides a comparison between the composition of expenditures with the compensation and without it, i.e. inclusive of the "fictitious capital outlay" for office buildings of 17.9 million kuna and exclusive of it.

\footnotetext{
${ }^{13}$ A points-system should be established to assess the technical, financial and administrative development of local units, and their ability to plan and manage their assets in a prudent way.

${ }^{14}$ Explanation of the city budget realization for 1999 (annual financial statement of the city budget for 1999 with associated documentation).
} 
Table 10. Comparison between total budget expenditure with the set-off and without it

\begin{tabular}{lrrrr} 
& 1999 & $1999 *$ & 1999 & $1999^{*}$ \\
\hline Outlays & $\begin{array}{r}\text { million } \\
\text { kuna }\end{array}$ & $\begin{array}{r}\text { million } \\
\text { kuna }\end{array}$ & $\%$ & $\%$ \\
\hline Current outlays & 54.7 & 54.7 & 67.0 & 85.8 \\
Capital outlays & 22.8 & 4.9 & 27.9 & 7.6 \\
Granted loans and the share in the principal & 3,9 & 3.9 & 4.7 & 6.1 \\
Repayment of principal & 0.2 & 0.2 & 0.3 & 0.4 \\
Reserve & 0.1 & 0.1 & 0.1 & 0.2 \\
\hline Total & 81.7 & 63.8 & 100.0 & 100.0 \\
\hline
\end{tabular}

Source: The City Income and Expenditure Accounts for the Period 1996 through 2000, from the Annual Budget Proposal for 1999.

* Budget outlays exclusive of the "fictitious capital outlay" for office buildings in the amount of 17.9 million kuna.

The inclusion of the "fictitious capital outlay" results in underreporting of the current expenditure by $17 \%$, and over reporting of capital outlays by $27 \%$. A more detailed analysis of budget expenditure reveals the following problems:

\section{Problem 3: Large Outlays for Culture}

Until 1999, the largest budget outlays were current transfers to citizens, households and nonfinancial organizations (mainly transfers for culture). According to Table 11, these outlays dropped from about 48\% in 1996 to about $27 \%$ of total budget expenditure in 1999 .

Table 11. Comparison between the total budget expenditure with the compensation and without it (in \%)

\begin{tabular}{|c|c|c|c|c|c|}
\hline Outlays and other payments & 1996 & 1997 & 1998 & 1999 & $1999^{*}$ \\
\hline 1. Current outlays & 98.5 & 99.0 & 91.6 & 67.0 & 85.8 \\
\hline $\begin{array}{l}\text { 1.1. Employment outlays, expenditures and regular } \\
\text { maintenance }\end{array}$ & 16.5 & 14.7 & 16.4 & 17.7 & 22.7 \\
\hline 1.2. Current outlays for materials and services & 6.5 & 4.8 & 5.0 & 9.5 & 12.1 \\
\hline $\begin{array}{l}\text { 1.3. Current transfers to citizens, households and non- } \\
\text { financial organizations (culture) }\end{array}$ & 48.5 & 44.7 & 44.6 & 27.0 & 34.6 \\
\hline 1.4. Other current transfers and grants (utilities) & 27.0 & 34.8 & 25.5 & 12.7 & 16.3 \\
\hline 2. Capital outlays & 1.3 & 0.8 & 4.7 & 27.9 & 7.6 \\
\hline 3. Granted loans and the share in principal & 0.0 & 0.0 & 1.3 & 4.7 & 6.1 \\
\hline 4. Repayment of principal & 0.0 & 0.0 & 2.2 & 0.3 & 0.4 \\
\hline 5. Reserve & 0.2 & 0.3 & 0.3 & 0.1 & 0.2 \\
\hline Total & 100 & 100 & 100 & 100 & 100 \\
\hline
\end{tabular}

As shown in Table 11, by excluding the compensation, i.e. the "fictitious capital outlay", from the total budget expenditure for 1999, we find out that the outlays for culture still represent the largest share in the budget expenditure (35\%). The reason behind the large outlays for culture is that the city has been host to a festival and has always been a cultural and tourist center. So it covers all costs of cultural activities (salaries of employees and material costs) and, for a small part, the costs of about 20 cultural institutions (e.g. City Museum, Library, Theater, Symphony Orchestra, etc.) 


\section{Problem 4: Large Transfers to Public Utility Companies and High Budget Liabilities (Borrowing, Co-Debtor Arrangements and Issuance of Guarantees)}

According to Table 11, other current transfers and grants ${ }^{15}$ represented the second largest budget outlay until 1998. In 1997, they accounted for about 35\%, and in 1999 for about $13 \%$, or $16 \%$ (exclusive of the "fictitious capital outlay") of total budget expenditure.

The Law on Utility Fees defines the utility fees as budget revenue of a local self-government unit, and the city is obliged to use the revenue collected from these fees for precisely determined purposes. The revenue from utility fees is mainly used for the payment of public utility companies' services (these companies are largely owned by the city). Although the situation in utility services was seemingly improving in 1999, and transfers dropped to about $13 \%$ of total budget expenditure, the real picture was different.

Instead of providing budget transfers to public utility companies, a new financial instrument has been implemented since 1998. Owing to general illiquidity, the unfavorable economic situation and cash shortage, indirect (postponed or "extrabudgetary") financing was introduced as from 1998. The city ceased to pay its obligations and issue warrants and guarantees for utility companies' loans (thus creating a potential debt to the budget). That is since these warrants and guarantees are likely to be activated in near future and the utility companies that are in a bad financial position will not be able to repay them, the warrants and guarantees will finally be financed from the budget.

Table 12. Total spending of the city (total outlays, other liabilities and city debt)

\begin{tabular}{|c|c|c|c|c|c|c|c|c|}
\hline & \multicolumn{2}{|c|}{1996} & \multicolumn{2}{|c|}{1997} & \multicolumn{2}{|c|}{1998} & \multicolumn{2}{|c|}{1999} \\
\hline & $\begin{array}{r}\text { million } \\
\text { kuna }\end{array}$ & $\%$ & $\begin{array}{r}\text { million } \\
\text { kuna }\end{array}$ & $\%$ & $\begin{array}{r}\text { million } \\
\text { kuna }\end{array}$ & $\%$ & $\begin{array}{r}\text { million } \\
\text { kuna } \\
\end{array}$ & $\%$ \\
\hline Total outlays & 50.0 & 100.0 & 67.9 & 94.0 & 70.4 & 66.0 & 81.7 & 61.0 \\
\hline Other liabilities & 0.1 & 0.0 & 4.2 & 6.0 & 11.4 & 11.0 & 21.9 & 16.0 \\
\hline City debt & & & & & 25.0 & 23.0 & 31.4 & 23.0 \\
\hline $\begin{array}{l}\text { Total spending } \\
\text { of the city }\end{array}$ & 50.1 & 100.0 & 72.1 & 100.0 & 106.8 & 100.0 & 135.0 & 100.0 \\
\hline
\end{tabular}

Source: City Balance Sheet as at 31 December 1999; total expenditure - as reported in the budget.

Other liabilities include liabilities to contractors, employees and other liabilities not mentioned.

The city debt relates to budgetary liabilities (based on borrowing, co-debtor arrangements and issuance of guarantees).

Table 12 indicates that the direct financing of the city expenditure from the city budget is on the decrease (the item: total expenditure). In 1996, the city paid all its liabilities via the budget, while in 1999 this type of financing was only applied to $61 \%$ of the city's liabilities. To put it simply, the current budget does not reflect the real situation (but only 61\% of the total spending of the city), because it does not include other liabilities (liabilities to contractors and employees, as well as other liabilities not mentioned), or city debt (guarantees, co-debtor arrangements etc.). By including other arrears and the city debt, in 1998 city spending would have amounted to approximately 107 million kuna, instead of 70 million kuna, and in 1999 it would have been 135 million kuna instead of 82 million kuna. Smaller outlays are reported in the budget because of the application of cash basis accounting. Thus, the city does not finance a part of budgetary spending (in 1999 it defaulted on the payment of $16 \%$ of its liabilities to contractors, employees etc.), and

\footnotetext{
${ }^{15}$ This position relates to:

1. grants to non-financial organizations, or co-financing the activities of public reconstruction enterprises in the city area;

2. maintenance of the communal hygiene standards in the city by regular monthly grants to public utility companies for the implementation of programs adopted by the City Council; and

3. costs of the tourist boards operation in the city area.
} 
in the same year it "covered up" $23 \%$ of its potential total expenditure by not recording it directly in the budget, but issuing numerous warrants, guarantees and concluding co-debtor arrangements. Thus it created an illusion of a balanced budget, while at the same time it accumulated a huge city debt without recording it directly in its budget.

\section{Problem 5: The Capital Assets Register - Unregulated Property-Rights Relations with Other Municipalities}

The bookkeeping records do not contain the part of the former municipality-city property, which the city currently uses, because there are still unregulated property-rights relations with newly established municipalities. To be more specific, an efficient management of budgetary assets requires a precise definition of the city's assets and their value. The capital assets register would certainly help through at least some of the problems with which this budget is confronted. It would make possible for an urgent sale of unnecessary city assets and using these receipts for the settlement of major outstanding liabilities of the city.

\section{Conclusion}

This paper analyses the lowest level of government - the city in Croatia, and is aimed at exploring its financial situation and establishing the key problems connected with decentralization at this level of government. The analysis is based on the data until 1999/2000, and it would be interesting to update these data and compare them with more recent figures (if, and when they become available) in order to assess the impact of the changes that occurred in the meantime on the above mentioned problems, i.e. the state of the budget, its transparency and reliability.

The following problems have been observed on the revenue side of the budget: huge uncollected receivables of the city, i.e. and incomplete and untimely collection of revenues (particularly utility fees, revenue from rentals and city taxes). In addition, time for repayment of loans which city has given to utility companies is constantly being extended, by the city. Given the efforts of the government to improve the overall liquidity in the country, it is likely that liquidity will grow, but this problem should be resolved by a more efficient implementation of all legal measures available to the city for improving the revenue collection (e.g. law suits, seizures etc.). Another solution could be to use international experience and engage private firms to collect all debts older than one year, for example. The firms would render these services against a fee. Thus at the state level, it would certainly be necessary to lay down a solid and reliable legal and institutional framework to facilitate the solution of the above mentioned problem and many other problems in the country.

The low level of revenue from grants to the city from other levels of government point to a need to restructure the current system of grants making it more transparent and clear, and to use various grants to respond to numerous problems. Otherwise it would be necessary to determine an optimum level of fiscal decentralization, which would include, apart from decentralization of public expenditure, delegation of wider powers to the lower levels of government to collect revenues.

On the expenditure side there are large transfers to the culture and public utilities, a problem of large arrears and issued guarantees for loans of utility companies (as an indirect, deferred /offbalance/ financing of public utility companies).

All these problems should be resolved by improving the public expenditure management. It is necessary to improve the functioning of all budgetary institutions. At the state level, this requires a consequent implementation of the current budget related legislation (three-year budget planning, maintenance of strict budgetary limitations) and more transparency (application of accruals basis accounting). Furthermore, it is necessary to develop human, technical, financial and administrative capacities at lower levels of government, as well as to improve the planning and prudential asset management skills, which also includes drawing up and keeping of the capital 
assets register. Financial management at lower levels of government should be improved by devolving more responsibilities and raising the awareness of the responsibility for managing the budget, exercising control of operations and imposing sanctions, where necessary, against the responsible persons. 


\section{LITERATURE:}

Bahl, R. 2000. »Implementation rules«, a paper presented within the Program of Fiscal Decentralization, Cambridge: Harvard Institute for International Development.

Bajo, A., 1999. »Zašto i kako mjeriti fiskalni kapacitet lokalnih jedinica«. Financijska praksa, 23 (3), 277-308.

CBS, 1998; Statistical Yearbook 1998, Zagreb: Central Bureau of Statistics.

Horváth, T. M., 1999. Decentralization: Experiments and Reforms. Budapest: Local Government and Public Service Reform Initiative.

Kelly, R., 2000. »Fiscal Decentralization Principles and Definition«, a paper presented within the Program of Fiscal Decentralization, Cambridge: Harvard Institute for International Development.

OECD, 2001. OECD Economic Outlook. Paris: OECD.

Ministarstvo financija, 2001., Godišnje izvješće Ministarstva financija za 2000. godinu. Zagreb: Ministarstvo financija.

Musgrave, R. A., 1993. Javne financije u teoriji i praksi. Zagreb: Institut za javne financije.

Rosen, H. S., 1999. Javne financije. Zagreb: Institut za javne financije.

Šimović, J., 1999. Temeljna obilježja financiranja javnih potreba jedinica lokalne samouprave i uprave. Porezni vjesnik, 8 (3), 56-69.

Šimović, J., 2000. »Mjesto i uloga fiskalnih i nefiskalnih instrumenata u financiranju javnih potreba jedinica lokalne samouprave u Republici Hrvatskoj« u: Zbornik radova: Tendencije u razvoju finacijske aktivnosti države. Zagreb: HAZU.

Ter-Minassian, T., 1997. Fiscal Federalism in Theory and Practice. Washington DC: International Monetary Fund.

Weist, D., 2000. »Intergovermental grants", a paper presented within the Program of Fiscal Decentralization, Cambridge: Harvard Institute for International Development.

Official documents of the observed city

The city Income and Expenditure Accounts for the period 1996 through 2000, from the Annual Budget Proposals

City Bulletin, No. 7/1999

Overall City Revenue and Expenditure Outturns (annual accounts for 1996, 1997 and 1998), Ministry of Finance of the Republic of Croatia, Budget Preparation and Consolidation Department 


\section{INSTITUTE OF PUBLIC FINANCE - OCCASIONAL PAPER SERIES}

No. $1 \quad$ State Intervention for Growth Promotion in Market Economies Marina Kesner Škreb, January 197

No. 2 Estimate of Revenues from the Value Added Tax in the Republic of Croatia Danijela Kuliš and Žarko Miljenović, October 1997

No. 3 The Unofficial Economy in Croatia: Causes, Size and Consequences Ivo Bićanić and Katarina Ott, November 1997

No. 4 Price Effects of VAT Introduction in Croatia Martina Dalić, December 1997

No. 5 Tax Administration Reform in Transition: The Case of Croatia Katarina Ott, April 1998

No. 6 The Present Sate of the Croatian Public Debt Zoran Bubaš, December 1998

No. 7 Public Investment in Croatia Katarina Ott and Anto Bajo, March 1999.

No. 8 Welfare Policy and Social Transfers in Croatia Predrag Bejaković and Alastair McAuley, July 1999

No. $9 \quad$ Is Unofficial Economy a Source of Corruption? Vedran Šošić and Michael Faulend, November 1999

No. 10 Banking Sector Problems: Causes, Resolutions and Consequences Ljubinko Jankov, March 2000

No. 11 Toward a Long - Term Strategy of Economic Development of Croatia: Where to Begin, What to Do, and How to Do It?

Dubravko Mihaljek, June 2001

No. 12 The Underground Economy in Croatia Katarina Ott, March 2002

No. 13 An Estimate of the Extent of Tax Evasion in Croatia Sanja Madžarević Šujster, April 2002

No. 14 Opportunism, Institutions and Moral Costs: The Socio-Cultural Dimension of the Underground Economy in Croatia 1995 - 1999

Aleksandar Štulhofer and Ivan Rimac, April 2002

No. 15 Dollarisation and the Underground Economy: Accidental Partners?

Vedran Šošić and Michael Faulend, April 2002

No. 16 Decentralization in the Republic of Croatia - A City Budget in the Period from 1996 to 2000, Mihaela Pitarević, March 2003 